\title{
Phylogenetic relationships among members of the Comamonadaceae, and description of Delftia acidovorans (den Dooren de Jong 1926 and Tamaoka et al. 1987) gen. nov., comb. nov.
}

\author{
Aimin Wen, ${ }^{1,2}$ Mark Fegan, ${ }^{1}$ Chris Hayward, ${ }^{1,2}$ Sukumar Chakraborty ${ }^{1,3}$ \\ and Lindsay I. Sly ${ }^{1,2}$
}

\author{
Author for correspondence: Lindsay I. Sly. Tel: +6173365 2396. Fax: +61 733651566. \\ e-mail: sly@ biosci.uq.edu.au
}

\footnotetext{
1,2 Cooperative Research Centre for Tropical Plant Pathology ${ }^{1}$ and Department of Microbiology Centre for Bacterial Diversity and Identification ${ }^{2}$, The University of Queensland, Brisbane, QLD 4072, Australia

${ }^{3}$ CSIRO Tropical Agriculture, St Lucia, QLD 4067, Australia
}

\begin{abstract}
The phylogenetic relationships among members of the family Comamonadaceae and several unclassified strains were studied by direct sequencing of their PCR-amplified 16S rRNA genes. Based on the 16S rRNA gene sequence analysis, members of the family formed a coherent group. The closest relatives are species of the Rubrivivax sub-group: Leptothrix discophora, Ideonella dechloratans and Rubrivivax gelatinosus. The genus Hydrogenophaga formed two subclusters, as did the species of Acidovorax, whereas the five species of the genus [Aquaspirillum] were polyphyletic. Comamonas acidovorans was phylogenetically distant from the type species of Comamonas, Comamonas terrigena. On the basis of this work and previous studies, Comamonas acidovorans is removed from the genus Comamonas and renamed as Delftia acidovorans gen. nov., comb. nov. Descriptions of the new genus Delftia and of the type species Delftia acidovorans, for which the type strain is ATCC 15668', are presented.
\end{abstract}

Keywords: phylogeny, 16S rDNA, taxonomy, Comamonadaceae, Delftia acidovorans

\section{INTRODUCTION}

Members of the Comamonadaceae, originally the acidovorans rRNA complex (De Vos et al., 1985; Willems et al., 1987, 1989, 1990), belong to rRNA superfamily III (De Ley 1978) or the $\beta$ subclass of the Proteobacteria (Stackebrandt et al., 1988). The family Comamonadaceae was described by Willems et al. (1991a) to include the genera Comamonas, Acidovorax, Hydrogenophaga, Xylophilus and Variovorax, as well as a number of phylogenetically misnamed [Aquaspirillum] and phytopathogenic [Pseudomonas] species based on relationships determined by extensive DNA-rRNA hybridization data. Later, Willems et al. (1992b) assigned the phylogenetically misnamed phytopathogenic Pseudomonas species ([Pseudomonas] avenae, [Pseudomonas] rubrilineans, '[Pseudomonas $]$ setariae', [Pseudomonas] cattleyae, [Pseudomonas] pseudoalcaligenes subsp. citrulli and [Pseudomonas] pseudoalcaligenes subsp. konjaci) to the genus Acido-

The GenBank accession numbers for the 165 rDNA sequences determined in this study are AF078753-AF078774. vorax. The nearest phylogenetic relatives of the Comamonadaceae are [Pseudomonas] saccharophila, Rubrivivax gelatinosus, Leptothrix and Sphaerotilus (Willems et al., 1991a).

Subsequently, several other species have been assigned to the Comamonadaceae. On the basis of 16S rRNA sequences, Hiraishi (1994) demonstrated that Rhodoferax fermentans was most closely related to Comamonas testosteroni, and later Hiraishi et al. (1995) assigned Rhodoferax fermentans and the newly described Brachymonas denitrificans to this family. Two strains from activated sludge and the Baltic Sea were found to be related to Comamonas testosteroni using in situ hybridization with oligonucleotide probes (Koivula \& Hantula, 1997), but their phylogenetic position and taxonomic status are not known. Recently, the causative organism of bacterial leaf spot on Anthurium sp. (Prior \& Rott, 1989) was found to belong to the genus Acidovorax (Saddler et al., 1995). However, its relationship to the existing species of Acidovorax is not clear.

Current knowledge of the phylogenetic relationship of the members of the Comamonadaceae is based on 
rRNA cistron similarities (Pot et al., 1992b; Willems et al., 1991a, b, 1992b), which was the most valid and useful parameter for drawing taxonomic conclusions at the generic and suprageneric levels before $16 \mathrm{~S}$ rRNA sequence analysis was available (Tamaoka et al., 1987). Based on the DNA-rRNA hybridization results (Pot et al., 1992b; Willems et al., 1991a, b, 1992b), sixteen rRNA branches within the Comamonadaceae were delineated: five Comamonas rRNA branches, one Hydrogenophaga rRNA branch, one Xylophilus rRNA branch, one Variovorax rRNA branch, two Acidovorax rRNA branches and six [Aquaspirillum] rRNA branches. Willems et al. (1987) and Vandamme et al. (1996) concluded that each of the sub-branches in the acidovorans rRNA complex (i.e. the Comamonadaceae) deserves a generic rank, provided that sufficient phenotypic and genotypic data are available to describe them. Because of the limit of resolution of DNA-rRNA hybridization data and the expanding number of members, the phylogenetic relationships within the family Comamonadaceae are yet to be fully elucidated. The sixteen rRNA branches do not correspond to the generic classification. For example, the genus Comamonas comprises five separate rRNA branches (Willems et al., 1991b) and the genus Acidovorax consists of two rRNA branches (Willems et al., 1992b).

Comparative sequence analysis of the 16S rRNA gene is currently one of the most powerful and reliable methods to estimate phylogenetic relationships among bacterial taxa. Prior to the commencement of this study, only four 16S rDNA sequences of bacteria belonging to the family Comamonadaceae were available (Hiraishi, 1994; Hiraishi et al., 1995; Yang et al., 1985). The purpose of this study was to use $16 \mathrm{~S}$ rDNA sequence similarity analysis to elucidate the precise phylogenetic relationships among members of the Comamonadaceae and to provide a more complete set of $16 \mathrm{~S}$ rDNA sequences for future taxonomic studies.

\section{METHODS}

Bacterial strains and cultivation. The 22 bacterial strains used in this study are listed in Table 1 . Several species studied are assigned to incorrect genera and these combinations are indicated by enclosing the genus name in square brackets. The [Aquaspirillum] species were grown on PSS agar (Pot et al., 1992b), Xylophilus ampelinus was grown on GYCA medium (Willems et al., 1987), and all other species were grown on medium B of King et al. (1954). Xylophilus ampelinus was incubated at $24^{\circ} \mathrm{C}$, [Aquaspirillum] psychrophilum was grown at $20^{\circ} \mathrm{C}$, and all other species were grown at $28^{\circ} \mathrm{C}$, for $48-72 \mathrm{~h}$.

PCR amplification of 165 rRNA genes. A bacterial suspension $\left(10^{8}\right.$ c.f.u. $\left.\mathrm{ml}^{-1}\right)$ was boiled for $10 \mathrm{~min}$ to release the DNA and centrifuged for $5 \mathrm{~min}$ in a microcentrifuge. The supernatant was used as DNA template for PCR amplification of the $16 \mathrm{~S}$ rRNA gene. PCR amplification was performed in a $100 \mu \mathrm{l}$ reaction volume containing PCR buffer $[67 \mathrm{mM}$

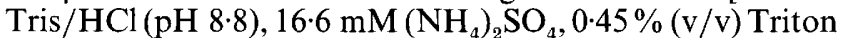
$\mathrm{X}-100,200 \mu \mathrm{g}$ gelatin $\left.\mathrm{ml}^{-1}\right], 1.5 \mathrm{mM} \mathrm{MgCl}$, each deoxynucleoside phosphate at a concentration of $200 \mu \mathrm{M}$,
$0.25 \mu \mathrm{M}$ primer $27 \mathrm{f}$ (Lane, 1991), $0.25 \mu \mathrm{M}$ primer $1525 \mathrm{r}$ (Lane, 1991), $5 \mu \mathrm{l}$ lysed cells and $2 \mathrm{U}$ Tth Plus DNA polymerase (Biotech International). A negative control was always included in each experiment, which contained all of the ingredients described above except for the template DNA.

All PCR amplifications were performed in a Perkin-Elmer Cetus model 480 thermal cycler (Applied Biosystems). The PCR conditions consisted of an initial denaturation step at $96^{\circ} \mathrm{C}$ for $5 \mathrm{~min} ; 28$ cycles of $48^{\circ} \mathrm{C}$ for $1 \mathrm{~min}, 72^{\circ} \mathrm{C}$ for $2 \mathrm{~min}$ and $94^{\circ}$ for $1 \mathrm{~min}$; and one additional cycle at $48^{\circ} \mathrm{C}$ for $1 \mathrm{~min}$ and $72{ }^{\circ} \mathrm{C}$ for $5 \mathrm{~min}$ to allow all extension products to be completed. The PCR products were purified by using the Promega Wizard Minipreps DNA purification system according to the manufacturer's instructions (Promega).

16S rDNA sequencing. The purified PCR product was used as the template for sequencing. Taq DyeDeoxy Terminator Cycle or ABI PRISM Dye Terminator Cycle sequencing kits (both from Applied Biosystems) were used following procedures recommended by the manufacturer. The following nine $16 \mathrm{~S}$ rDNA sequencing primers were used in the sequencing reactions: $27 \mathrm{f}, 342 \mathrm{r}, 357 \mathrm{f}, 519 \mathrm{r}, 530 \mathrm{f}, 907 \mathrm{r}, 1114 \mathrm{f}$ and 1525r (Lane, 1991); and 803f (Stackebrandt \& Charfreitag, 1990). The sequencing products were purified according to the manufacturer's instructions. The sequences were determined on an Applied Biosystems 373A DNA sequencer.

Phylogenetic analysis. The 16S rDNA sequences were manually aligned using the ae 2 editor program (Maidak et al., 1997) against the existing sequences obtained from GenBank for Comamonas testosteroni and other reference species (Burkholderia cepacia, Brachymonas denitrificans, Variovorax paradoxus, Rhodoferax fermentans, Ideonella dechloratans, Leptothrix discophora, Rubrivivax gelatinosus and Spirillum volutans) belonging to the $\beta$-Proteobacteria. The phylogenetic tree shown in Fig. 1 was constructed by comparison of 1309 nucleotide positions. Ambiguous nucleotide positions, where alignment was uncertain, were excluded from the analysis. The sequence of Burkholderia cepacia ATCC $25416^{\mathrm{T}}$ was used as the outgroup in the phylogenetic analyses. The construction of the phylogenetic trees was computed using two different methods of phylogenetic analysis (parsimony and distance) available in the PHYLIP software package, version 3.5 (Felsenstein, 1993). Pairwise evolutionary distances were calculated by the method of Jukes \& Cantor (1969) using the DNADIST program, and the parsimony analysis was performed using DNAPARS. A dendrogram was constructed from evolutionary distance values by using the neighbour-joining method of Saitou \& Nei (1987) contained in the NEIGHBOR program of PHYLIP. The tree topologies and statistical significance of branch points of the distance and parsimony trees were tested by 100 bootstrap resamplings of the data (Felsenstein, 1985).

Nucleotide sequence accession numbers. The 16S rDNA sequences determined in this study have GenBank accession numbers AF078753-AF078774 (Table 1). The strain numbers and the nucleotide sequence accession numbers for the reference strains are as follows: Burkholderia cepacia ATCC 25416 ${ }^{\mathrm{T}}$, M22518; Comamonas testosteroni RH1104 (= ATCC $11996^{\mathrm{T}}$ ), M11224; Brachymonas denitrificans AS-P1 (= JCM 9216 $),$ D14320; Variovorax paradoxus IAM 12373 ${ }^{\mathrm{T}}$, D30793; Rhodoferax fermentans FR 2 (= JCM 7819 $)$, D16211; Polaromonas vacuolata strain 34-P $\mathrm{P}^{\mathrm{T}}(=$ ATCC $51984^{\mathrm{T}}$ ), U14585; Ideonella dechloratans CCUG 
Table 1. Strains used in 16S rRNA gene sequencing

ACM, Australian Collection of Microorganisms, Department of Microbiology, The University of Queensland, St Lucia, Australia; ATCC, American Type Culture Collection, Manassas, VA, USA; CCUG, Culture Collection of the University of Göteborg, Department of Clinical Bacteriology, University of Göteborg, Sweden; DSM, Deutsche Sammlung von

Mikroorganismen, Braunschweig, Germany; Hantula, J. Hantula, University of Helsinki, Finland; ICMP, Culture Collection of the Plant Disease Division, New Zealand Department of Scientific and Industrial Research, Auckland, New Zealand; IMI, International Mycological Institute, Egham, Surrey, UK; LMG, Culture Collection Laboratorium voor Microbiologie, State University of Ghent, Ghent, Belgium; NICB, National Collection of Industrial Bacteria, Aberdeen, UK; NCPPB, National Collection of Plant-pathogenic Bacteria, Central Science Laboratory, York, UK.

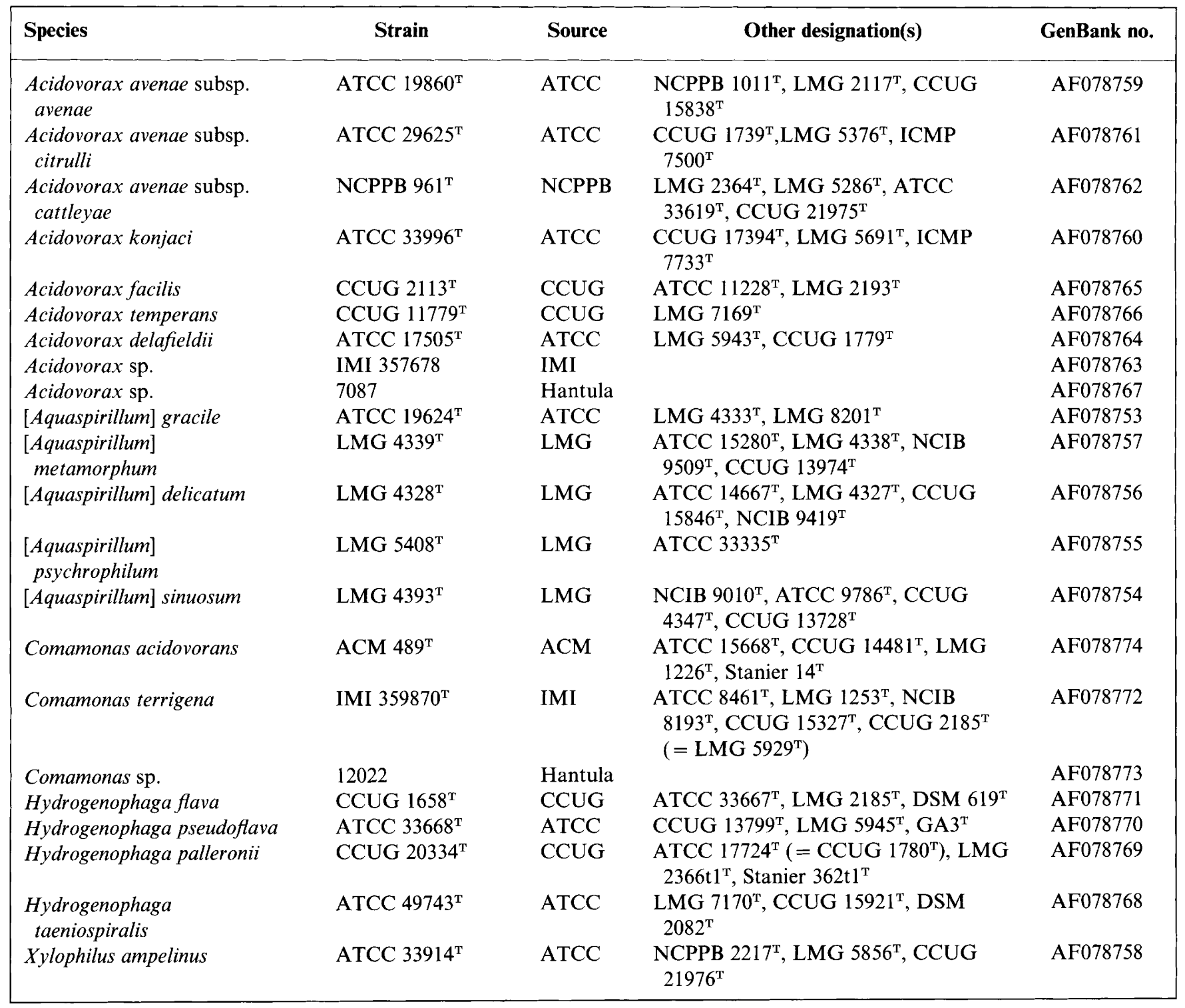

$30898^{\mathrm{T}}$ (= ATCC 15173 $)$, X72724; Leptothrix discophora SS-1 (= ATCC 43182), Z18533; Rubrivivax gelatinosus strain A3 ( = ATCC $\left.17011^{\mathrm{T}}\right)$, D16213; and Spirillum volutans ATCC 19554, M34131.

\section{RESULTS AND DISCUSSION}

Nearly complete $16 \mathrm{~S}$ rDNA sequences ( $>1500$ nucleotides) were determined for the 22 strains listed in Table 1 . The phylogenetic relationships among mem- bers of the family Comamonadaceae, determined by a neighbour-joining distance analysis of their $16 \mathrm{~S} \mathrm{rDNA}$ sequences (Fig. 1), were by and large in agreement with the relationships deduced from rRNA cistron similarities (Pot et al., 1992b; Willems et al., 1991a, b, $1992 \mathrm{~b}$ ). The relationships inferred from a parsimony analysis of the data were similar to those obtained by the distance analysis. A more detailed phylogenetic picture at the generic and intrageneric levels was obtained with the 16S rDNA sequence analysis than 


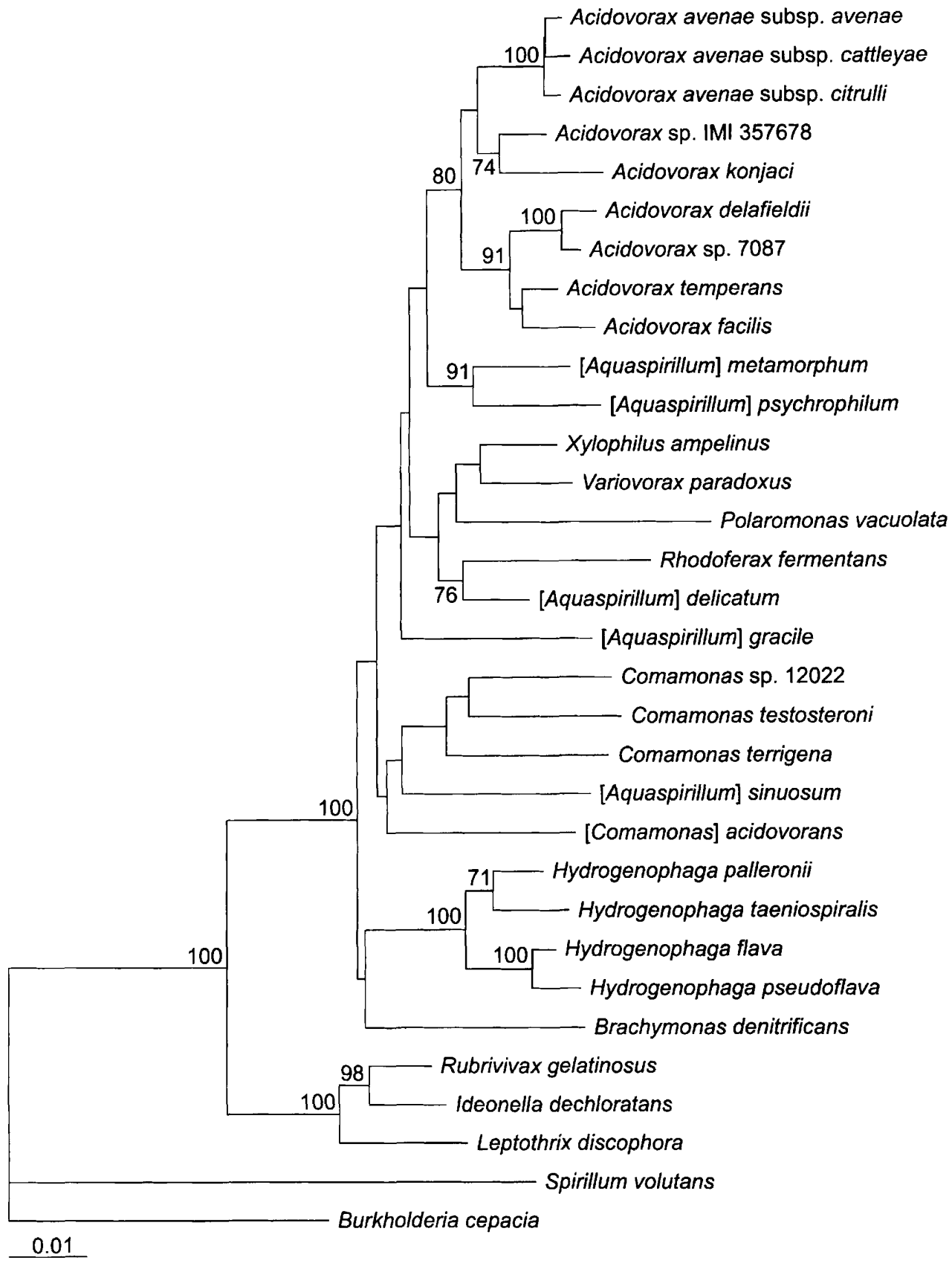

Fig. 1. Neighbour-joining tree showing phylogenetic relationships among members of the family Comamonadaceae and related species based on 1309 nucleotide positions of their 16S rDNA sequences. Burkholderia cepacia was used as the outgroup. Scale bar represents 1 nucleotide substitution per 100 nucleotides. Bootstrap values of 100 resamplings are shown at the branch points.

had been obtained from the previous rRNA cistron similarities. Each of the rRNA branches within the Comamonadaceae determined by rRNA cistron analysis (Pot et al., 1992b; Willems et al., 1991a, b, 1992b) for the genera Comamonas, Acidovorax, Variovorax, Xylophilus, Hydrogenophaga and [Aquaspirillum] have been confirmed by $16 \mathrm{~S}$ rDNA sequence analysis. In addition the polyphyletic nature of the genus Comamonas and the misclassified [Aquaspirillum] species has been confirmed.

\section{The genus Comamonas}

The three species of the type genus Comamonas (Comamonas terrigena, Comamonas testosteroni and Comamonas acidovorans) belong to deep, poorly supported branches, a finding in agreement with DNArRNA hybridization results of Willems et al. (1991b). These workers demonstrated that there were five rRNA branches within the genus Comamonas which were linked to other rRNA branches in the family 
Comamonadaceae at a $T_{\mathrm{m}}(\mathrm{e})$ value of $76 \pm 1 \cdot 1{ }^{\circ} \mathrm{C}$. The five rRNA branches consisted of one Comamonas acidovorans branch, one Comamonas testosteroni branch and three Comamonas terrigena branches. We included only the type strain IMI $359870^{\mathrm{T}}$ of Comamonas terrigena (genotype 1) in our study. The results of our 16S rRNA gene sequence analysis (Fig. 1) showed that Comamonas testosteroni and Comamonas terrigena formed a deeply branched cluster. However, Comamonas acidovorans occurs on a very deep branch of uncertain phylogenetic position and cannot be considered a member of the genus Comamonas. This result confirms previous reports based on DNArRNA hybridization (Willems et al., 1991b), 16S rRNA cataloguing (Woese et al., 1984a, b) and conventional and chemotaxonomic methods (Tamaoka et al., 1987). A numerical analysis of morphological, physiological and biochemical characters, protein gel electrophoresis and immunotyping experiments (Willems et al., 1991b) also suggested that the species Comamonas acidovorans should be removed from the genus Comamonas. The strain 12022 from the Baltic sea (Koivula \& Hantula, 1997) clustered with Comamonas testosteroni, although the bootstrap value for this branch point was only $61 \%$ for the neighbourjoining tree and the sequence similarity was $96.3 \%$. The similarity value of strain 12022 to the existing species of Comamonas, inferred from the 16S rDNA sequence analysis, ranged from 93.1 to $96 \cdot 3 \%$, which suggests it does not belong to any of the existing species of the genus Comamonas (Stackebrandt \& Goebel, 1994). The taxonomic position of strain 12022 requires further investigation.

\section{The genus Acidovorax}

Within the genus Acidovorax, the validly described species (Acidovorax avenae, Acidovorax konjaci, Acidovorax facilis, Acidovorax temperans, Acidovorax delafieldii), the strain 7087 from activated sludge (Koivula \& Hantula, 1997) and the Anthurium pathogen strain IMI 357678 (Saddler et al., 1995) clustered together. The level of the 16S rDNA sequence similarity of the species of Acidovorax and strains 7087 and IMI 357678 ranged from 95.8 to $99.5 \%$, which revealed that the genus Acidovorax is phylogenetically homogeneous. However, the species of Acidovorax diverged into two sub-groups. The first sub-group consisted of all the phytopathogens including Acidovorax avenae, Acidovorax konjaci and the Anthurium pathogen strain IMI 357678 , and the second sub-group comprised the nonphytopathogenic species Acidovorax facilis, Acidovorax temperans, Acidovorax delafieldii and the strain 7087 from activated sludge. The two sub-groupings deduced from 16S rDNA sequence analysis support the results obtained by rRNA cistron similarities (Willems et al., 1992b) which showed that Acidovorax avenae and Acidovorax konjaci formed one rRNA branch, and Acidovorax facilis, Acidovorax temperans, Acidovorax delafieldii formed another rRNA branch; the two rRNA branches were linked at a $T_{\mathrm{m}}(\mathrm{e})$ value of $77^{\circ} \mathrm{C}$. In our results there is high bootstrap support for the branch containing the non-phytopathogens, but little support (bootstrap value of $47.0 \%$ for the distance tree) for the phytopathogen branch. The three subspecies of Acidovorax avenae are very closely related, sharing sequence similarities of over $99.5 \%$. The Anthurium pathogen strain IMI 357678 was most closely related to Acidovorax konjaci, a relationship which was not revealed previously by random-amplified polymorphic DNA analysis (RAPD) (Saddler et al., 1995). Strain IMI 357678 shared a sequence similarity of $98.1 \%$ with Acidovorax konjaci; this strain appears to be a new species but its taxonomic standing will need to be resolved by DNA-DNA hybridization. The activated sludge strain 7087 has a sequence similarity of $99.3 \%$ with Acidovorax delafieldii. However, cells of this strain were non-motile short rods or coccobacilli, unlike the cells of Acidovorax delafieldii which are straight rods $(0.5 \times$ $1.8-2.6 \mu \mathrm{m})$, and are motile by means of a single polar flagellum (Palleroni, 1984). The taxonomic identity of strain 7087 needs to be defined by DNA-DNA hybridization and the availability of more phenotypic data.

\section{The genus Hydrogenophaga}

The four species of Hydrogenophaga formed a tight group with very high bootstrap support $(100 \%$ for the distance tree and $95 \%$ for the parsimony tree). The 16S rDNA sequences of the four species exhibited levels of similarity in the range from 97.0 to $99 \cdot 1 \%$. There is some evidence of a bifurcation within the genus with Hydrogenophaga flava and Hydrogenophaga pseudoflava forming one sub-group, and Hydrogenophaga taeniospiralis and Hydrogenophaga palleronii forming a second sub-group. This finding is in good agreement with results obtained by rRNA cistron similarity (Willems et al., 1989).

\section{The Polaromonas-Variovorax-Xylophilus branch}

The grapevine pathogen Xylophilus ampelinus clustered with Variovorax paradoxus and Polaromonas vacuolata. The closeness of the relationship between Xylophilus ampelinus and Variovorax paradoxus was not previously revealed by DNA-rRNA hybridization studies (Willems et al., 1987). The 16S rDNA sequence similarity of $97.9 \%$ between these two taxa indicates a closer relationship than is expected between two separate genera. The type species of the two taxa exhibit $20 \%$ DNA-DNA reassociation indicating their separate species status (Willems et al., 1987). Phenotypically, these taxa exhibit similarities in cell morphology, positive reaction for catalase and production of a yellow non-diffusible pigment, whilst exhibiting differences in oxidase reaction, flagella arrangement, growth temperature, chemolithotrophic growth with hydrogen, nitrate reduction, habitat and utilization of carbon sources (Willems et al., 1987, 1991a, b). The taxonomic status of these two taxa may 
need to be revised following a more polyphasic characterization.

The newly described species Polaromonas vacuolata clusters with Xylophilus ampelinus and Variovorax paradoxus and has $94.5 \%$ and $94.8 \%$ sequence simlarity, respectively, although the grouping is not well supported by bootstrap values. Polaromonas vacuolata was previously shown (Irgens et al., 1996) to be most closely related to Variovorax paradoxus, but in the absence of a sequence for Xylophilus ampelinus, the relationship with this species was not revealed. Polaromonas vacuolata is a psychrophilic chemo-organotroph from marine Antarctic waters, and the first gas vacuolate member of the Comamonadaceae and the $\beta$ Proteobacteria (Irgens et al., 1996).

\section{The Brachymonas branch}

The newly described species Brachymonas denitrificans falls on a separate deep branch of the Comamonadaceae and is the only known member of the branch. Hiraishi et al. (1995) found Brachymonas denitrificans to group with Comamonas testosteroni but used too few reference sequences to adequately infer the relationship of this species with other members of the Comamonadaceae. The cells of this species are nonmotile coccobacilli or short rods (Hiraishi et al., 1995). They have a similar cell morphology to strains 7087 and 12022 (results not shown), but the three strains are not phylogenetically related according to their $16 \mathrm{~S}$ rRNA gene sequences.

\section{Misclassified [Aquaspirillum] species}

Based on DNA-rRNA hybridization, Pot et al. (1992b) determined that seven species of [Aquaspirillum] belong to the family Comamonadaceae whereas the type species of the genus Aquaspirillum, Aquaspirillum serpens, belongs to the Aquaspirillum serpens rRNA branch in rRNA superfamily III. The species [Aquaspirillum] anulus, [Aquaspirillum] delicatum, [Aquaspirillum] metamorphum, [Aquaspirillum] sinuosum, [Aquaspirillum] giesbergeri, [Aquaspirillum] gracile and [Aquaspirillum] psychrophilum are phylogenetically distinct and cannot be considered as members of this genus. Pot et al. (1992b) showed that among the seven misclassified Aquaspirillum species, only [Aquaspirillum] giesbergeri and [Aquaspirillum] sinuosum are closely related; all other species occupy separate positions in the acidovorans rRNA complex. Each distinct rRNA branch is indicative of generic rank (Vandamme et al., 1996). We determined the 16S rDNA sequences for five of these species, but were unable to obtain viable cultures of [Aquaspirillum] anulus and [Aquaspirillum] giesbergeri which therefore have not been included in this study. Our 16S rDNA sequence analysis revealed that the five species of [Aquaspirillum] examined are deeply branching in accordance with the results demonstrated by rRNA cistron similarities (Pot et al., 1992b; Willems et al., 1991a). The results showed that the species [Aqua- spirillum] psychrophilum and [Aquaspirillum] metamorphum are closely related, sharing a sequence similarity of $97.2 \%$, and that [Aquaspirillum] delicatum and Rhodoferax fermentans clustered together on a separate deep branch with a sequence similarity of $96 \cdot 8 \%$. The precise phylogenetic positions of [Aquaspirillum] sinuosum and [Aquaspirillum] gracile are unclear due to deep branching with low bootstrap support, but they show no close relationship to any other well-supported branches within the Comamonadaceae. In general, the deep branchings and low bootstrap values make it difficult to confirm the relationship between the misclassified species of [Aquaspirillum] and the genus Acidovorax, which was revealed by Willems et al. (1992b). Using rRNA cistron similarity, Willems et al. demonstrated that the [Aquaspirillum] strains have significantly higher $T_{\mathrm{m}}(\mathrm{e})$ values versus rRNA from either Acidovorax avenae NCPPB $1011^{\mathrm{T}}$ or Acidovorax facilis ATCC $11228^{\mathrm{T}}$ than to the other taxa of the Comamonadaceae. Recently, the chemotaxonomic characterizations of the genus [Aquaspirillum] were reported (Hamana et al., 1994; Sakane \& Yokota, 1994). Based on polyamine patterns (Hamana et al., 1994), the seven species of [Aquaspirillum] are separated into two groups: 2-hydroxyputrescine-putrescine type containing [Aquaspirillum] anulus, [Aquaspirillum] delicatum, $[$ Aquaspirillum $]$ gracile, $[$ Aquaspirillum $]$ giesbergeri, [Aquaspirillum] metamorphum and [Aquaspirillum] sinuosum, and 2-hydroxyputrescine-putrescine-spermidine type containing [Aquaspirillum] psychrophilum only. This grouping does not agree with our 16S rRNA gene sequence analysis, nor with the result of DNA-rRNA hybridization (Pot et al., 1992b). Studies on the fatty acid compositions have shown that the seven [Aquaspirillum] species were heterogeneous in 3-hydroxy fatty acid: [Aquaspirillum] anulus, [Aquaspirillum] giesbergeri, [Aquaspirillum] metamorphum and [Aquaspirillum] sinuosum have 3-OH 10:0; [Aquaspirillum] delicatum has 3-OH 8:0; [Aquaspirillum] psychrophilum has 3-OH 10:0 and 8:0; and [Aquaspirillum] gracile has 3-OH 10:0 and 12:0 as major 3hydroxy fatty acid (Sakane \& Yokota, 1994). Grouping using this chemotaxonomic marker does not correlate with our results either.

\section{Closest neighbours of the family Comamonadaceae}

The 16S rDNA sequence analysis determined that the species Rubrivivax gelatinosus, Ideonella dechloratans and Leptothrix discophora are the closest relatives of the family Comamonadaceae, which confirmed results previously obtained by DNA-rRNA hybridization (Willems et al., 1991a). No 16S rRNA sequence is available for [Pseudomonas] saccharophila, which was therefore not included in the analysis.

\section{Taxonomic considerations}

The 16S rDNA sequence analysis of members of the Comamonadaceae has confirmed that this is a coherent phylogenetic group and has extended knowledge of the 
relationships at intrageneric and generic levels. We have resolved several taxonomic issues, some of which have been identified by other workers. However, resolution of other issues will require further research. The major questions to be addressed in the future are whether the phytopathogenic and non-phytopathogenic species of Acidovorax belong to separate genera, the transfer of [Comamonas] acidovorans to a new genus, the transfer of [Aquaspirillum] psychrophilum and [Aquaspirillum] metamorphum to a new genus, and the transfer of [Aquaspirillum] gracile and [Aquaspirillum] sinuosum to new genera. Further work is also required to clarify the relationship between [Aquaspirillum] delicatum and Rhodoferax fermentans, and between Variovorax paradoxus and Xylophilus ampelinus. At this time, a start can be made on the taxonomic revision of the genus Comamonas. There is sufficient phylogenetic and phenotypic evidence to remove the species [Comamonas] acidovorans from the genus Comamonas, and for its transfer to a new genus for which we propose the name Delftia.

\section{Description of Delftia gen. nov.}

Delftia (Delf.'tia. M.L. fem. n. Delftia referring to the city of Delft, the site of isolation of the type species, and in recognition of the pioneering role of Delft research groups in the development of bacteriology). The description is based on data from previous research (Busse \& Auling, 1988; De Vos et al., 1985; Ikemoto et al., 1978; Palleroni, 1984; Tamaoka et al., 1987; Willems et al., 1989, 1991b, 1992a), and the present 16S rRNA gene sequence analysis.

Cells are straight to slightly curved rods, $0 \cdot 4-0.8 \times 2.5-4.1 \mu \mathrm{m}$ (occasionally up to $7 \mu \mathrm{m}$ ), which occur singly or in pairs. Motile by means of polar or bipolar tufts of one to five flagella. Gram-negative. Oxidase and catalase-positive. Endospores are not produced, and no fluorescent pigments are produced. Poly- $\beta$-hydroxybutyrate is accumulated in cells. Strictly aerobic, nonfermentative and chemo-organotrophic. Hydrolyses acetamide, nitrate reduced to nitrite, no levan formation from sucrose, gelatinliquefaction-negative, no starch hydrolysis, lipase (Tween 80 hydrolysis)-positive, arginine-dihydrolasenegative, meta cleavage of protocatechuate. Unable to denitrify. Unable to grow autotrophically with hydrogen. Cells grow well on media containing organic acids, amino acids, peptone and carbohydrates (but not glucose). Putrescine and 2-hydroxyputrescine are the main polyamine components. Ubiquinone Q-8 is the main quinone, Q-7 and Q-9 are minor quinones, but menaquinone is not produced. Major fatty acids are hexadecanoic acid (16:0), hexadecenoic acid (16:1) and octadecenoic acid (18:1); 3-hydroxy fatty acids (3-OH 10:0 and 8:0) are present, but 2-hydroxy fatty acid is not present. The mean $\mathrm{G}+\mathrm{C}$ content of the DNA ranges from 67 to $69 \mathrm{~mol} \%$ (as determined by the thermal denaturation method). The genus belongs to the family Comamonadaceae according to DNA-
rRNA hybridization (Willems et al., 1991a) and 16S rRNA gene sequence analysis. The characteristics differentiating Delftia from related genera are listed in Table 2. The type species of the genus is Delftia acidovorans.

\section{Description of Delftia acidovorans (den Dooren de Jong 1926 and Tamaoka et al. 1987) comb. nov.}

Delftia acidovorans (a.ci.do'vo.rans. L. neut. n. acidum acid; L. v. voro to devour; M.L. part. adj. acidovorans acid-devouring). The description is the same as that for the genus. A detailed description is given below based on information from Palleroni (1984), Tamaoka et al. (1987), Willems et al. (1991b) and the present $16 \mathrm{~S}$ rRNA gene sequence analysis.

Characteristics of the species are as follows: growth at $30{ }^{\circ} \mathrm{C}$, no growth at $4{ }^{\circ} \mathrm{C}$ and $41{ }^{\circ} \mathrm{C}$, growth in the presence of 0.5 or $1.5 \% \mathrm{NaCl}$, no pigment production on nutrient agar.

The following characteristics are absent: growth in the presence of $6.5 \% \mathrm{NaCl}$; acid production in $10 \%$ lactose, in triple sugar iron medium and in oxidativefermentative medium containing D-glucose, D-fructose, D-xylose, maltose, or adonitol; production of $\mathrm{H}_{2} \mathrm{~S}$ in triple sugar iron medium; hydrolysis of aesculin, gelatin and DNA; indole production; $\beta$-galactosidase activity; hydrolysis of 2-naphthylmyristate, L-valyl-2-naphthylamide, $\quad N$-benzoyl-DL-arginine-2naphthylamide, $N$-glutaryl-phenylalanine-2-naphthylamide, 6-bromo-2-naphthyl- $\alpha$-D-galactopyranoside, 2 -naphthyl- $\beta$-D-galactopyranoside, naphthol-AS-BI$\beta$-D-glucuronate, 2 -naphthyl- $\alpha$-D-glucopyranoside, 6bromo-2-naphthyl- $\beta$-D-glucopyranoside, 1-naphthyl$N$-acetyl- $\beta$-D-glucosaminide, 6-bromo-2-naphthyl- $\alpha$ D-mannopyranoside and 2-naphthyl- $\alpha$-L-fucopyranoside.

The following organic compounds can be utilized as carbon and energy sources: acetate, acetamide [reported as a variable reaction by Tamaoka et al. (1987) and Willems et al. (1991b)], aconitate, adipate, Dalanine [reported as a variable reaction by Willems $e t$ al. (1991b)], L-alanine [reported as a variable reaction by Willems et al. (1991b)], 2-aminobutyrate [reported as a variable reaction by Willems et al. (1991b)], $\delta$ aminovalerate, L-aspartate, azelate, butanol, 2,3-butylene glycol, butyrate, caproate [reported as a variable reaction by Willems et al. (1991b)], citraconate, citrate [reported as a variable reaction by Willems et al. (1991 b)], ethanol, D-fructose, fumarate, gluconate, L-glutamate, glutarate, glycerate, glycine [reported as a variable reaction by Willems et al. (1991b)], glycolate, hippurate, L-histidine, $m$-hydroxybenzoate, $p$-hydroxybenzoate, $\beta$-hydroxybutyrate, hydroxymethylglutarate, isobutyrate, L-isoleucine [reported as a variable reaction by Willems et al. (1991b)], isovalerate, itaconate, $\alpha$-ketoglutarate, kynurenate, L-kynurenine, lactate, levulinate, L-leucine, $D$ malate [reported as a variable reaction by Willems $e t$ 
Table 2. Differential characteristics of the genus Delftia and other genera in the family Comamonadaceae

+ , Present in all species; - , absent in all species; $(+)$, weak reaction; $d, 11-89 \%$ of strains positive; D, variable reaction in different species; NA, no data available. References: $a$, De Vos et al. (1985), Palleroni (1984), Tamaoka et al. (1987) and Willems et al. (1991b); b, De Vos et al. (1985), Palleroni (1984), Tamaoka et al. (1987) and Willems et al. (1991b); $c$, Palleroni (1984) and Willems et al. (1990, 1992b); d, Palleroni (1984) and Willems et al. (1989); e, Kersters \& De Ley (1984), Urakami et al. (1995) and Willems et al. (1991a); $f$, Bradbury (1984) and Willems et al. (1987, 1991a); g, Hiraishi et al. (1991); $h$, Hiraishi et al. (1995); $i$, Irgens et al. (1996); j, Hamana et al. (1994), Krieg (1984), Pot et al. (1992a, b) and Sakane \& Yokota (1994).

\begin{tabular}{|c|c|c|c|c|c|c|c|c|c|c|}
\hline Character & Delftia $^{a}$ & Comamonas ${ }^{b}$ & Acidovorax ${ }^{c}$ & Hydrogenophaga ${ }^{d}$ & Variovorax & Xylophilusf & Rhodoferax ${ }^{g}$ & Brachymonas $^{k}$ & Polaromonas & (Aquaspirillum ( $^{j}$ \\
\hline Cell morphology & Rods & Rods or spirilla & Rods & Rods & Rods & Rods & Curved rods & $\begin{array}{l}\text { Coccobacilli or } \\
\text { short rods }\end{array}$ & Rods & $\begin{array}{l}\text { Spirilla or } \\
\text { curved rods }\end{array}$ \\
\hline Flagella & $\begin{array}{l}\text { Polar or } \\
\text { bipolar tufts }\end{array}$ & $\begin{array}{c}\text { Polar or } \\
\text { bipolar tufts }\end{array}$ & One polar & One polar & Peritrichous & One polar & One polar & - & One polar & $\begin{array}{l}\text { Bipolar tufts or } 1-2 \\
\text { flagella at only } \\
\text { one pole }\end{array}$ \\
\hline Pigments & - & - & - & + & + & + & - & $(+)$ & - & - \\
\hline \multicolumn{11}{|l|}{ Occurrence: } \\
\hline Soil & + & + & + & + & + & - & - & - & - & - \\
\hline Fresh water & + & + & + & + & + & - & - & - & - & + \\
\hline Marine water & - & - & - & - & - & - & - & - & + & - \\
\hline Infected plants & - & - & + & - & - & + & - & - & - & - \\
\hline Clinical samples & + & + & + & - & - & - & - & - & - & - \\
\hline Activated sludge & + & + & + & - & $\mathrm{NA}$ & NA & + & + & - & - \\
\hline Phototrophy & - & - & - & - & - & - & + & - & - & - \\
\hline Oxidase & + & + & + & + & + & - & + & + & + & + \\
\hline $\begin{array}{l}\text { Chemolithotrophic } \\
\text { growth with } \mathrm{H}_{2}\end{array}$ & - & - & D & + & $\mathrm{D}$ & - & $\mathrm{NA}$ & $\mathrm{NA}$ & - & $\mathrm{NA}$ \\
\hline Psychrophilic growth & - & - & - & - & - & - & - & - & + & - \\
\hline Growth factors & - & D & - & - & - & L-Glutamate & $\begin{array}{l}\text { Biotin and } \\
\text { thiamine }\end{array}$ & - & - & $\mathrm{D}$ \\
\hline Denitrification & - & - & $\mathrm{D}$ & $\mathrm{D}$ & - & - & - & + & - & $\mathrm{D}$ \\
\hline \multicolumn{11}{|l|}{$\begin{array}{l}\text { Carbon source used for } \\
\text { growth }\end{array}$} \\
\hline Acetamide & $\mathrm{d}$ & - & $\mathrm{D}$ & - & - & NA & $\mathrm{NA}$ & $\mathrm{NA}$ & $\mathrm{NA}$ & $\mathrm{NA}$ \\
\hline$\beta$-Alanine & d & - & $\mathrm{D}$ & - & d & $\mathrm{NA}$ & - & $\mathrm{NA}$ & $\mathrm{NA}$ & $\mathrm{NA}$ \\
\hline 2-Aminobutyrate & $\mathrm{d}$ & - & $\mathrm{D}$ & $\mathrm{D}$ & $\mathrm{NA}$ & $\mathrm{NA}$ & $\mathrm{NA}$ & - & $\mathrm{NA}$ & $\mathrm{NA}$ \\
\hline 3-Aminobutyrate & $\mathrm{d}$ & D & $\mathrm{D}$ & D & NA & NA & NA & - & NA & $\mathrm{NA}$ \\
\hline D-Fructose & + & - & + & $\mathrm{D}$ & $\mathrm{NA}$ & - & + & - & - & - \\
\hline D-Glucose & - & - & $\mathrm{D}$ & + & + & + & + & - & + & $\mathrm{D}$ \\
\hline Glycerol & $\mathrm{d}$ & $\mathrm{D}$ & + & + & + & + & - & - & + & $\mathrm{D}$ \\
\hline Malonate & $\mathrm{d}$ & - & D & - & $\mathrm{d}$ & - & NA & - & - & $\mathrm{D}$ \\
\hline D-Mannitol & + & - & $\mathrm{D}$ & $\mathrm{D}$ & $\mathrm{NA}$ & - & + & - & NA & NA \\
\hline Maleate & d & - & $\mathrm{D}$ & - & $\mathrm{d}$ & - & $\mathrm{NA}$ & NA & $\mathrm{NA}$ & $\mathrm{NA}$ \\
\hline Phenylacetate & d & - & - & - & $\mathrm{d}$ & $\mathrm{NA}$ & $\mathrm{NA}$ & $\mathrm{NA}$ & $\mathrm{NA}$ & $\mathrm{NA}$ \\
\hline $\mathrm{L}-(+)$-Tartrate & d & - & - & $\mathrm{D}$ & d & $\mathrm{NA}$ & NA & - & NA & $\mathrm{D}$ \\
\hline D-Tryptophan & d & $\mathrm{D}$ & - & - & $\mathrm{NA}$ & $\mathrm{NA}$ & $\mathrm{NA}$ & $\mathrm{NA}$ & $\mathrm{NA}$ & - \\
\hline L-Tryptophan & d & - & $\mathrm{D}$ & $\mathrm{D}$ & d & $\mathrm{NA}$ & $\mathrm{NA}$ & - & $\mathrm{NA}$ & - \\
\hline Major quinone system & Q-8 & Q-8 & Q-8 & Q-8 & Q-8 & $\mathrm{Q}-8+\mathrm{RQ}-8$ & $\mathrm{Q}-8+\mathrm{RQ}-8$ & NA & Q-8 & \\
\hline $\begin{array}{l}\text { Major cellular fatty } \\
\text { acid(s) }\end{array}$ & $\begin{array}{l}16: 0 \\
16: 1 \\
18: 1\end{array}$ & $\begin{array}{l}16: 0 \\
16: 1 \\
18: 1\end{array}$ & $\begin{array}{l}16: 0 \\
16: 1 \\
18: 1\end{array}$ & $\begin{array}{l}16: 0 \\
16: 1\end{array}$ & $\begin{array}{l}16: 1 \\
16: 0 \\
18: 1\end{array}$ & $\mathrm{NA}$ & $\begin{array}{l}16: 0 \\
16: 1\end{array}$ & $\begin{array}{l}16: 0 \\
16: 1\end{array}$ & $\begin{array}{c}16: 1 \omega 7 \mathrm{c} \\
16: 0 \\
18: 1 \omega 7 \mathrm{c}, \\
18: 1 \omega 9 \mathrm{t} \\
\quad \text { or } \\
18: 1 \omega 12 \mathrm{t}\end{array}$ & $\begin{array}{l}16: 0 \\
16: 1\end{array}$ \\
\hline Major 3-OH acids & $\begin{array}{c}10: 0 \\
8: 0\end{array}$ & $10: 0$ & $\begin{array}{l}10: 0 \\
8: 0\end{array}$ & $\begin{array}{c}8: 0 \\
(10: 0)\end{array}$ & $10: 0$ & $\mathrm{NA}$ & $8: 0$ & $10: 0$ & $\mathrm{NA}$ & $10: 0$ \\
\hline $\mathrm{G}+\mathrm{C}$ content $(\mathrm{mol} \%)$ & $67-69$ & $63-66$ & $67-70$ & $65-69$ & $66-68$ & $68-69$ & $\begin{array}{c}\text { 59-61 } \\
\text { (HPLC } \\
\text { method) }\end{array}$ & $\begin{array}{c}\text { 63-65 } \\
\text { (HPLC method) }\end{array}$ & $52-57$ & $56-62$ \\
\hline
\end{tabular}

al. (1991b)], L-malate, maleate [reported as a variable reaction by Willems et al. (1991b)], malonate [reported as a variable reaction by Willems et al. (1991b)], mannitol, mesaconate, mucate, nicotinate, DL-norleucine [reported as a variable reaction by Willems et al. (1991b)], L-norleucine [reported as a variable reaction by Willems et al. (1991b)], DL-norvaline, phenylacetate [reported as a variable reaction by Willems et al. (1991b)], L-phenylalanine [reported as a variable reaction by Willems et al. (1991b)], pimelate, L-proline, $n$ propanol, propionate, pyruvate, quinate, saccharate, sebacate, suberate, succinate, $\mathrm{L}-(+)$-tartrate [reported as a variable reaction by Willems et al. (1991b)], mtartrate, trigonelline [reported as a negative reaction by Willems et al. (1991b)], L-tryptophan [reported as a variable reaction by Tamaoka et al. (1987) and Willems et al. (1991b)], D-tryptophan [reported as a variable reaction by Willems et al. (1991b)], L-tyrosine and valerate.

The following compounds are not utilized by the species: $N$-acetylglucosamine, adonitol, 3-aminobenzoate, amylamine, anthranilate, D-arabinose, Larabinose, D-arabitol, L-arabitol, arbutin, L-arginine, 
benzoate [reported as a variable reaction by Willems et al. (1991b)], benzoylformate, benzylamine, betaine, butylamine, caprylate, cellobiose, L-citrulline, creatine, L-cysteine, diaminobutane, dodecane, dulcitol, aesculin, erythritol, ethanolamine, ethylamine, ethylene glycol [reported as a positive reaction by Tamaoka et al. (1987)], $\mathrm{D}$-fucose [reported as a variable reaction by Willems et al. (1991b)], D-galactose, $\beta$-gentiobiose, geraniol, glucosamine, D-glucose, methyl $\alpha$-D-glucoside, glycogen, heptanoate, hexadecane, histamine, $o$ hydroxybenzoate, poly- $\beta$-hydroxybutyrate, DL- $\beta$ hydroxybutyrate, inulin, isophthalate, 2-ketogluconate, 5-ketogluconate, lactose, L-lysine, D-lyxose, maltose, $\mathrm{D}$-mandelate, $\mathrm{L}$-mandelate [reported as a variable reaction by Willems et al. (1991b)], D-mannose, methyl- $\alpha$-D-mannoside, D-melezitose, D-melibiose, naphthalene, L-ornithine, oxalate, pantothenate, pelargonate [reported as a variable reaction by Willems et al. (1991b)], phenol, phenylethanediol, phthalate [reported as a variable reaction by Willems et al. (1991b)], propylene glycol [reported as a positive reaction by Tamaoka et al. (1987)], putrescine, Lrhamnose, D-raffinose, D-ribose, salicin, sarcosine [reported as a variable reaction by Willems et al. (1991b)], L-serine, sorbitol, L-sorbose, spermine, sucrose, starch, D-( - )-tartrate, terephthalate, testosterone, L-theronine [reported as a positive reaction by Tamaoka et al. (1987) and a variable reaction by Willems et al. (1991b)], D-turanose, trehalose, tryptamine, urea, L-valine [reported as a variable reaction by Willems et al. (1991b)], $m$-xylitol, D-xylose, L-xylose and methyl $\beta$-D-xyloside.

Variable utilizations among different strains: $\beta$-alanine, 2-aminobenzoate, 4-aminobenzoate, 3-aminobutyrate, 4-aminobutyrate, 5-aminobutyrate, $\alpha$-aminovalerate, amygdalin, 2,3-butylene glycol, caprate, glycerol, $m$-erythritol, heptanoate, $m$-inositol, isobutanol, DL-kynurenine, L-methionine and tagatose.

Strains have been isolated from soil, sediment, activated sludge, crude oil, oil brine, water and various clinical samples. The $\mathrm{G}+\mathrm{C}$ values of the DNA range from 67 to $69 \mathrm{~mol} \%$ (as determined by the thermal denaturation method). Belongs to the family Comamonadaceae based on the 16S rRNA gene sequence analysis.

The type strain is ATCC $15668^{\mathrm{T}}$ (den Dooren de Jong $7^{\mathrm{T}}$; Stanier $14^{\mathrm{T}}$; ACM $489^{\mathrm{T}}$; LMG $1226^{\mathrm{T}}$ NCIB $9681^{\mathrm{T}}$ ). The type strain was isolated from soil enriched with acetamide in Delft in the Netherlands in 1926. The characteristics of the type strain are the same as those given above for the species. The $\mathrm{G}+\mathrm{C}$ value of the DNA of strain Stanier $14^{\mathrm{T}}$ is $67 \mathrm{~mol} \%$ (as determined by the thermal denaturation method).

\section{ACKNOWLEDGEMENTS}

We are grateful to CCUG and Dr J. Hantula for providing bacterial isolates. Aimin Wen is indebted to AusAID for a scholarship and the Australian Grains Research and Development Corporation for research funding.

\section{REFERENCES}

Bradbury, J. F. (1984). Genus II. Xanthomonas Dowson 1939. In Bergey's Manual of Systematic Bacteriology, vol. 1, pp. 199-210. Edited by N. R. Krieg \& J. G. Holt. Baltimore: Williams \& Wilkins.

Busse, J. \& Auling, G. (1988). Polyamine pattern as a chemotaxonomic marker within the Proteobacteria. Syst Appl Microbiol 11, 1-8.

De Ley, J. (1978). Modern molecular methods in bacterial taxonomy: evolution, application, prospects. In Proceedings of the 4th International Conference of Plant Pathogenic Bacteria, vol. 1, pp. 347-357. Tours: Gibert-Clarey.

De Vos, P., Kersters, K., Falsen, E., Pot, B., Gillis, M., Segers, P. \& De Ley, J. (1985). Comamonas Davis and Park 1962 gen. nov., nom. rev. emend., and Comamonas terrigena Hugh 1962 sp. nov., nom. rev. Int $J$ Syst Bacteriol 35, 443-453.

Felsenstein, J. (1985). Confidence limits on phylogenies: an approach using the bootstrap. Evolution 39, 783-791.

Felsenstien, J. (1993). PHYLIP (phylogeny inference package), version $3.5 \mathrm{c}$, Seattle: Department of Genetics, University of Washington.

Hamana, K., Sakane, T. \& Yokota, A. (1994). Polyamine analysis of the genera Aquaspirillum, Magnetospirillum, Oceanospirillum and Spirillum. J Gen Appl Microbiol 40, 75-82.

Hiraishi, A. (1994). Phylogenetic affiliations of Rhodoferax fermentans and related species of phototrophic bacteria as determined by automated $16 \mathrm{~S}$ rDNA sequencing. Curr Microbiol 28, 25-29.

Hiraishi, A., Hoshino, Y. \& Satoh, T. (1991). Rhodoferax fermentans gen. nov., sp. nov., a phototrophic purple nonsulfur bacterium previously referred to as the "Rhodocyclus gelatinosus-like" group. Arch Microbiol 155, 330-336.

Hiraishi, A., Shin, Y. K. \& Sugiyama, J. (1995). Brachymonas denitrificans gen. nov., sp. nov., an aerobic chemoorganotrophic bacterium which contains rhodoquinones, and evolutionary relationships of rhodoquinone producers to bacterial species with various quinone classes. J Gen Appl Microbiol 41, 99-117.

Ikemoto, S., Kuraishi, H., Komagata, K., Azuma, R., Suto, T. \& Murooka, H. (1978). Cellular fatty acid composition in Pseudomonas species. J Gen Appl Microbiol 24, 199-213.

Irgens, R. L., Gosink, J. J. \& Staley, J. T. (1996). Polaromonas vacuolata gen. nov., sp. nov., a psychrophilic, marine, gas vacuolate bacterium from Antarctica. Int J Syst Bacteriol 46, $822-826$.

Jukes, T. H. \& Cantor, C. R. (1969). Evolution of protein molecules. In Mammalian Protein Metabolism, pp. 21-132. Edited by H. N. Munro. New York: Academic Press.

Kersters, K. \& De Ley, J. (1984). Genus Alcaligenes Castellani and Chalmers 1919. In Bergey's Manual of Systematic Bacteriology, vol. 1, pp. 361-373. Edited by N. R. Krieg \& J. G. Holt. Baltimore: Williams \& Wilkins.

King, E. O., Ward, W. K. \& Raney, D. E. (1954). Two simple media for the demonstration of pyocyanin and fluorescein. $J \mathrm{Lab}$ Clin Med 44, 301-307.

Koivula, T. T. \& Hantula, J. (1997). Diversity within bacterial isolates hybridizing with Comamonas probe ppT. $J$ Basic Microbiol 37, 129-137.

Krieg, N. R. (1984). Genus Aquaspirillum Hylemon, Wells, Krieg and Jannasch 1973. In Bergey's Manual of Systematic Bacteriology, vol. 1, pp. 72-90. Edited by N. R. Krieg \& J. G. Holt. Baltimore: Williams \& Wilkins. 
Lane, D. J. (1991). 16S/23S rRNA sequencing. In Nucleic Acid Techniques in Bacterial Systematics, pp. 115-175. Edited by E. Stackebrandt \& M. Goodfellow. Chichester: Wiley.

Maidak, B. L., Olsen, G. J., Larsen, N., Overbeck, R., McCaughey, R. \& Woese, C. R. (1997). The RDP (Ribosomal Database Project). Nucleic Acids Res 25, 109-110.

Palleroni, N. J. (1984). Genus I. Pseudomonas Migula 1894. In Bergey's Manual of Systematic Bacteriology, vol. 1, pp. 141-199. Edited by N. R. Krieg \& J. G. Holt. Baltimore: Williams \& Wilkins.

Pot, B., Gillis, M. \& De Ley, J. (1992a). The genus Aquaspirillum. In The Prokaryotes, 2 nd edn, vol. 3 , pp. 2569-2582. Edited by A. Balows, H. G. Trüper, M. Dworkin, W. Harder \& K.-H. Schleifer. New York: Springer.

Pot, B., Willems, A., Gillis, M. \& De Ley, J. (1992b). Intra- and intergeneric relationships of the genus Aquaspirillum: Prolinoborus, a new genus for Aquaspirillum fasciculus, with the species Prolinoborus fasciculus comb. nov. Int $J$ Syst Bacteriol 42, 44-57.

Prior, P. \& Rott, P. (1989). Bacterial leaf spot of Anthurium (Anthurium spp.) caused by a Pseudomonas sp. in the French West Indies. Phytopathology 124, 215-224.

Saddler, G. S., O'Grady, E. B. \& Spence, J. A. (1995). Characterization of a pseudomonad-like bacterium pathogenic for Anthurium species. Bull OEPP 25, 211-217.

Saitou, N. \& Nei, M. (1987). The neighbor-joining method: a new method for reconstructing phylogenetic trees. Mol Biol Evol 4, 406-425.

Sakane, T. \& Yokota, A. (1994). Chemotaxonomic investigation of heterotrophic, aerobic and microaerophilic spirilla, the genera Aquaspirillum, Magnetospirillum, and Oceanospirillum. Syst Appl Microbiol 17, 128-134.

Stackebrandt, E. \& Charfreitag, O. (1990). Partial 16S rRNA primary structure of five Actinomyces species: phylogenetic implications and development of an Actinomyces israeliispecific oligonucleotide probe. J Gen Microbiol 136, 37-43.

Stackebrandt, E. \& Goebel, B. M. (1994). Taxonomic note: a place for DNA-DNA reassociation and 16S rRNA sequence analysis in the present species definition in bacteriology. Int $J$ Syst Bacteriol 44, 846-849.

Stackebrandt, E., Murray, R. G. E. \& Trüper, H. G. (1988). Proteobacteria classis nov., a name for the phylogenetic taxon that includes the "purple bacteria and their relatives". Int J Syst Bacteriol 38, 321-325.

Tamaoka, J., Ha, D. \& Komagata, K. (1987). Reclassification of Pseudomonas acidovorans den Dooren de Jong 1926 and Pseudomonas testosteroni Marcus and Talalay 1956 as Comamonas acidovorans comb. nov. and Comamonas testosteroni comb. nov., with an emended description of the genus Comamonas. Int J Syst Bacteriol 37, 52-59.

Urakami, T., Araki, H. \& Komagata, K. (1995). Characteristics of newly isolated Xanthobacter strains and fatty acid compositions and quinone systems in yellow-pigmented hydrogen-oxidizing bacteria. Int $J$ Syst Bacteriol 45, 863-867.
Vandamme, P., Pot, B., Gillis, M., De Vos, P., Kersters, K. \& Swings, J. (1996). Polyphasic taxonomy, a consensus approach to bacterial systematics. Microbiol Rev 60, 407-438.

Willems, A., Gillis, M., Kersters, K., Van den Broecke, L. \& De Ley, J. (1987). Transfer of Xanthomanas ampelina Panagopoulos 1969 to a new genus, Xylophilus gen. nov., as Xylophilus ampelinus (Panagopoulos 1969) comb. nov. Int $J$ Syst Bacteriol 37, 422-430.

Willems, A., Busse, J., Goor, M. \& 8 other authors (1989). Hydrogenophaga, a new genus of hydrogen-oxidising bacteria that includes Hydrogenophaga flava comb. nov. (formerly Pseudomonas flava), Hydrogenophaga palleronii (formerly Pseudomonas palleronii), Hydrogenophaga pseudoflava (formerly Pseudomonas pseudoflava and "Pseudomonas carboxydoflava"), and Hydrogenophaga taeniospiralis (formerly Pseudomonas taeniospiralis). Int J Syst Bacteriol 39, 319-333.

Willems, A., Falsen, E., Pot, B., Jantzen, E., Hoste, B., Vandamme, P., Gillis, M., Kersters, K. \& De Ley, J. (1990). Acidovorax, a new genus for Pseudomonas facilis, Pseudomonas delafieldii, E. Falsen(EF) Group 13, EF group 16, and several clinical isolates, with the species Acidovorax facilis comb. nov., Acidovorax delafieldii comb. nov., and Acidovorax temperans sp. nov. Int $J$ Syst Bacteriol 40, 384-398.

Willems, A., De Ley, J., Gillis, M. \& Kersters, K. (1991a). Comamonadaceae, a new family encompassing the acidovorans rRNA complex, including Variovorax paradoxus gen. nov., comb. nov., for Alcaligenes paradoxus (Davis 1969). Int J Syst Bacteriol 41, 445-450.

Willems, A., Pot, B., Falsen, E., Vandamme, P., Gillis, M., Kersters, K. \& De Ley, J. (1991b). Polyphasic taxonomic study of the emended genus Comamonas: relationship to Aquaspirillum aquaticum, E. Falsen group 10, and other clinical isolates. Int J Syst Bacteriol 41, 427-444.

Willems, A., De Vos, P. \& De Ley, J. (1992a). The genus Comamonas. In The Prokaryotes, 2nd edn, vol. 3, pp. 2583-2590. Edited by A. Balows, H. G. Trüper, M. Dworkin, W. Harder \& K.-H. Schleifer. New York: Springer.

Willems, A., Goor, M., Thielemans, S., Gillis, M., Kersters, K. \& De Ley, J. (1992b). Transfer of several phytopathogenic Pseudomonas species to Acidovorax avenae subsp. avenae subsp. nov., comb. nov., Acidovorax avenae subsp. citrulli, Acidovorax avenae subsp. cattleyae, and Acidovorax konjaci. Int J Syst Bacteriol 42, 107-119.

Woese, C. R., Blanz, P. \& Hahn, C. M. (1984a). What isn't a pseudomonad: the importance of nomenclature in bacterial classification. Syst Appl Microbiol 5, 179-195.

Woese, C. R., Weisburg, W. G., Paster, B. J., Hahn, C. M., Tanner, R. S., Krieg, N. R., Koops, H.-P., Harms, H. \& Stackebrandt, E. (1984b). The phylogeny of purple bacteria: the beta subdivision. Syst Appl Microbiol 5, 327-336.

Yang, D., Oyaizu, Y., Oyaizu, H., Olsen, G. J. \& Woese, C. R. (1985). Mitochondrial origins. Proc Natl Acad Sci USA 82, 4443-4447. 